ISSN 1392-3196 / e-ISSN 2335-8947

Zemdirbyste-Agriculture, vol. 104, No. 3 (2017), p. 277-282

DOI 10.13080/z-a.2017.104.035

\title{
Meat quality of different beef cattle breeds fed high energy forage
}

\author{
Vigilijus JUKNA ${ }^{1}$, Česlovas JUKNA ${ }^{2}$, Vaidotas PRUSEVIČIUS ${ }^{3}$, \\ Edita MEŠKINYTĖ-KAUŠILIENE ${ }^{4}$, Nijolè PEČIULAITIENE ${ }^{2}$ \\ ${ }^{1}$ Institute of Energy and Biotechnology Engineering, Aleksandras Stulginskis University \\ Studentų 11, Akademija, Kaunas distr., Lithuania \\ ${ }^{2}$ Veterinary Academy, Lithuanian University of Health Science \\ Tilžès 18, Kaunas, Lithuania \\ ${ }^{3}$ Ministry of Agriculture of the Republic of Lithuania \\ Gedimino 19, Vilnius, Lithuania \\ ${ }^{4}$ Center of Animal Husbandry Selections, Breeding Values and Dissemination, \\ Aleksandras Stulginskis University \\ Studentų 11, Akademija, Kaunas distr., Lithuania \\ E-mail: edita.kausiliene@asu.lt; dita.kausiliene@.asu.lt
}

\begin{abstract}
The aim of this study was to investigate the changes in meat quality characteristics of different beef cattle breeds fed high energy forage. The study included 200 days old uncastrated beef cattle of the following breeds: Limousin, Charolais, Angus, Hereford and Simmental. Feeding and housing conditions for bulls were the same. Animals were given a certain amount of concentrated forage plus silage ad libitum. The rest of the feed consisted of small amounts of grass and corn silage. When the bulls were 500 days old, 5 bulls from each group, best meeting the average indicators, were selected for control slaughter.

No substantial influence of breed on the amount of dry food was determined. The meat of Aubrac breed was determined to have the highest meat protein sufficiency rate, while the lowest rate was found in the meat of Hereford breed. The difference reached up to $1.79 \%(P<0.05)$. Differences between breeds for meat tenderness were observed as well. The toughest meat was from the Aubrac breed cattle, while the tenderest was from the Charolais breed meat. The difference reached up to $0.9 \mathrm{~kg} \mathrm{~cm}^{-2}(P<0.01)$. There were no significant differences between breeds for water content of meat, water holding capacity and cook loss. Intramuscular fat level varied according to the breed. The meat of Hereford breed was determined to have the highest level of intramuscular fat, while the lowest level was found in the Aubrac breed meat. The difference was $1.48 \%(P<0.05)$. Differences between breeds for physical meat quality were observed as well. The meat of French breeds (Charolais and Limousine) was lighter and had higher water holding capacity $-0.78-0.82 \%(P>0.05)$ as compared to the meat of English breeds (Hereford and Angus).
\end{abstract}

Key words: bulls, correlation, feed, meat quality, purebred.

\section{Introduction}

Herbaceous forage is widely used for cattle feeding and has an impact on meat quality and nutritional value because it is composed of fatty acids and vitamin $\mathrm{E}$.

"It has been shown that animals kept on pasture have higher concentrations of vitamin $\mathrm{E}$ in the muscle. Feeding grass silage caused a higher vitamin E concentration in beef compared to maize silage" (Schwarz et al., 2003). According to Canadian scientists, the level of vitamin $\mathrm{E}$ in the meat of bulls fed grass silage was two times higher as compared to the meat of bulls fed compound feed. The meat of bulls fed grass was determined to have a better flavour than the meat of grain- fed bulls (Aldai et al., 2011). However, "concentrate feeding resulted in higher intramuscular fat levels than grass-based feeding" and "growth performance of bulls was lower on the grass-based system compared with concentrates" (Nuernberg et al., 2005). The cattle meat production efficiency depends on how they were fed. When selecting beef cattle breeds for growing in a farm, it is important to assess the farmland and to ensure that animals would receive forage with proper energy content (Dierking et al., 2010). The high quality of meat from beef cattle indicates that offspring are fed high energy forage. If farmers are able to provide good quality forage

Please use the following format when citing the article: 
for beef cattle, then they can use the extensive beef cattle farming system (Jukna, Jukna, 2004). In order to produce a good quality meat, animals must be fed good quality forage. Rations for beef cattle must be balanced.

Beef biological value is determined by the essential amino acids and lipid structure (Raes et al., 2004; Serra et al., 2004). Beef is a source of proteins, minerals and vitamins. Thus, beef performs an important role in human diet (Jukna et al., 2006; 2008). However, consumers are concerned that red meat contains saturated fat and cholesterol (Ozluturk et al., 2004; Michal et al., 2006). It is known that not only the amount of fat but also the structure plays an important role in health maintenance (Vandendriessche, 2008; Wood et al., 2008). The amount of fat in meat can vary widely depending on various factors: species of animal, the particular cut of meat, the degree of separation of fat from the meat in various handling phases, cooking technique, etc. (Schonfeldt, Gibson, 2008; Taniguchi et al., 2008; Web, O'Neill, 2008). The highest quality of meat is produced from purebred cattle. Cattle breed is one of the very important factors that affect fat tissue distribution (Chambaz et al., 2003). At the same weight and degree of fatness, different breeds may have different proportions of intramuscular, intermuscular and subcutaneous fat (Purslow, 2005; Serdaroglu, 2006). Researchers Žgur and Čepon (2007) assessed that beef breeds (Hereford, Angus and Simmental) deposit more subcutaneous and less intramuscular fat. Beef quality describes the chemical composition and physical properties of meat (Jukna et al., 2010 a). The chemical composition of meat contains complex chemical compounds that determine its nutritional value (Jukna et al., 2008; 2009 b). The protein composition of muscle affects the colour and texture of the meat, water holding capacity and other properties (Jukna et al., 2006). In addition, muscle tissue contains lipids. The chemical composition of meat depends on species, animal age and sex, feeding conditions and health status. Physical properties of meat were evaluated according to its colour, $\mathrm{pH}$, water holding capacity, shear force and cooking loss (Vieira et al., 2007; Bendikas et al., 2008; Jukna et al., 2009 a; 2010 b). Water holding capacity is an important technological characteristic of meat (Vavrišinova et al., 2013). The colour and appearance of meat shows its marketability. The $\mathrm{pH}$ level determines the suitability of meat for sale and is associated with meat colour and water holding capacity (Rotta et al., 2009). Researchers Nuernberg et al. (2005) assessed that "muscle $\mathrm{pH}$ was higher in bulls on the grass-based system and muscle colour was darker in the animals on the grass-based diet and these animals had tougher meat as measured by shear force". Shear force is an important index for evaluating the meat quality. The amount of connective tissue and the structure of proteins influence shear force (Jukna et al., 2008; 2010 b). Since the appearance, tenderness, juiciness and flavour of meat affect consumers perception of quality, farmers should be aware of differences between breeds and meat quality which depends on feeding quality and housing conditions (Chambaz et al., 2003; Culioli et al., 2003; Jukna et al., 2006; Wood et al., 2008; Bendikas et al., 2009).

The aim of this study was to investigate the changes in meat quality characteristics of different beef cattle breeds fed high energy forage.

\section{Material and methods}

The research was carried out in 2015 and included 200 days old uncastrated beef cattle. The breeds tested included Limousin, Charolais, Angus, Hereford and Simmental. Animals were divided into two groups of 10. The control group included purebred bulls which were selected at age of 210 days. The slaughter age was 500 days. The bulls of each breed were under the same housing and feeding conditions at the company "Šilutès Breeding Sation". Concentrated animal feeding accounted for $48-50 \%$ of the total feed. Animals were given a certain amount of concentrated forage plus the silage ad libitum. The rest of feed consisted of small amounts of grass and corn silage.

The amount of feed consumed was calculated from the difference between the amount of given feed and the amount of feed left uneaten. Forage quality was analysed in laboratory "Žalvija". Combined forage was made according to the recipe Lit K 65-13/156 (PLC Kauno Grūdai, Lithuania). Forage consisted of barley, oats, rye bran, malt sprouts, sunflower meal, calcium carbonate, protein vitamin supplement and sodium chloride supplement VMP (Josera GmbH \& Co. KG, Germany) for bulls.

Feed composition is presented in the Table 1 .

The tested animals were weighted at the ages of 210 and 500 days. The daily weight gain and feed intake (kg of weight gain) were calculated according to the weighting data.

When the bulls were 500 days old, 5 bulls from each group, best meeting the average indicators, were selected for control slaughter. Meat quality tests were carried out at the Centre of Animal Husbandry Selections, Breeding Values and Dissemination, Aleksandras Stulginskis University. Meat samples for determination of meet quality were taken at the last ribs from the musculus longissimus dorsi. The meat quality evaluation was carried out $48 \mathrm{~h}$ after slaughter. The chemical composition and physical properties of meat were analysed. The analysis included the following features: dry materials (automatic instruments SM-1), ash (organic matter incineration at $600-800^{\circ} \mathrm{C}$ to constant weight), meat pH (pH-meter INOLAB3, Xylem Analytics Germany Sales GmbH \& Co. KG., Germany), meat colour (CIELAB) tristimulus values, lightness $\left(\mathrm{L}^{*}\right)$, redness $\left(\mathrm{a}^{*}\right)$ and yellowness ( $\left.b^{*}\right)(C R-400$ Chroma Meter, Konica Minolta Business Technologies Inc., Japan), drip loss (samples of $24 \mathrm{~h}$ ), water-holding capacity (Grau-Hamm (1953) method), total meat mass moisture content \% (Hamm (1972) pressing method), shear force (Warner (1928) and Bratzler (1932) method), cooking loss (Shiling method, AOAC method, 2011.003), fat (an automatic system for fat extraction, Soxterm method, AOAC method, 2011.003), proteins (Kjeldahl method, AOAC method, 2011.003), tryptophan (the Spies and Chambers method, AOAC method), oxyproline (Neuman and Logan method, AOAC method, 2011.003). The index of protein value was determined according to the relationship of amino acids: tryptophan and oxyproline.

Statistical analysis. The statistical package $R$, version 2.0.1 (Gentleman, Ihaka, 1997) was used to estimate data. The Student's $t$-test was used to determine differences among the means. Differences were considered statistically reliable when $P<0.05$. 
Table 1. The quality of forage per one kg in dry matter (DM)

\begin{tabular}{lccc}
\hline \multicolumn{1}{c}{ Indicators } & & The type of feed & grass silage \\
\cline { 2 - 4 } & compound feed & corn silage & 10.90 \\
\hline Feed energy MJ & 12.32 & 11.04 & 33.5 \\
Dry matter \% & 28.45 & 29.5 & 16.0 \\
Crude protein g & 13.91 & 9.8 & 4.4 \\
Crude fat g & 2.26 & 3.9 & - \\
Sugars g & 3.17 & 4.2 & 3.9 \\
Raw sugar g & - & 4.2 & 1.6 \\
Soluble sugar g & - & 3.2 & - \\
Starch g & - & 19.8 & 38.9 \\
Crude fibre & 5.13 & - & 26.5 \\
Neutral detergent fibre (NDF) & 32.9 & 36.9 & 4.4 \\
Acid detergent fibre (ADF) & 19.8 & 25.7 & 1.51 \\
Acid detergent lignin (ADL) & 3.7 & 3.9 & 0.02 \\
Calcium (Ca) g & 0.90 & 1.02 & 1.83 \\
Cobalt (Co) mg & 0.32 & 0.02 & 13.4 \\
Cuprum (Cu) mg & 7.20 & 1.25 & 0.34 \\
Manganese (Mn) mg & 12.00 & 10.5 & 1.89 \\
Selenium (Se) mg & 0.32 & 0.35 & 1.96 \\
Iodine (I) mg & 2.00 & 1.95 & 9.38 \\
Vitamin D3, thousand IU & 1.84 & 1.95 & 53.85 \\
Vitamin A, thousand IU & 9.20 & 9.45 & 53.08 \\
Vitamin E mg & 52.00 & & 1 \\
\hline
\end{tabular}

\section{Results and discussion}

The chemical composition of high energy forage for different breeds beef is presented in the Table 2 .

The data in the Table 2 shows that the highest amount of dry matter was observed in the Aubrac meat, while the lowest amount was in the Simmental bovine meat. The difference reached up to $2.08 \%(P<0.01)$. The highest level of protein was observed in the meat of Aubrac breed, while the Hereford meat had the lowest level of protein. The difference reached up to $1.79 \%(P<$ $0.05)$. According to the results, the Hereford meat was the highest in fat, whereas the Aubrac meat was the lowest. The difference reached up to $1.48 \%(P<0.05)$. The highest amount of ash was determined in the Hereford meat, while the lowest amount of ash was in the meat of Charolais breed. The difference was $0.11 \%(P<0.05)$.

CIE-LAB tristimulus values of the purebred Lithuanian meat are presented in the Table 3.

Table 2. The chemical composition of bovine meat according to different breeds

\begin{tabular}{lcccc}
\hline & \multirow{2}{*}{ Breed } & \multicolumn{4}{c}{ Chemical composition \% } \\
\cline { 2 - 5 } & dry matter & protein & fat & ashes \\
\hline Charolais & $24.87 \pm 0.25$ & $21.60 \pm 0.14$ & $2.19 \pm 0.27$ & $1.09 \pm 0.10$ \\
Simmental & $23.35 \pm 0.54$ & $21.77 \pm 0.27$ & $1.83 \pm 0.17$ & $1.10 \pm 0.03$ \\
Limousine & $24.50 \pm 0.26$ & $22.10 \pm 0.28$ & $1.24 \pm 0.15$ & $1.15 \pm 0.09$ \\
Hereford & $25.17 \pm 0.54$ & $21.44 \pm 0.27$ & $2.51 \pm 0.09$ & $1.20 \pm 0.07$ \\
Aubrac & $25.43 \pm 0.23$ & $23.23 \pm 0.34$ & $1.03 \pm 0.05$ & $1.17 \pm 0.11$ \\
Angus & $24.26 \pm 0.11$ & $20.47 \pm 0.81$ & $1.58 \pm 0.14$ & $1.15 \pm 0.12$ \\
\hline
\end{tabular}

Table 3. Colour parameters of Lithuanian purebred bovine meat

\begin{tabular}{lccc}
\hline & \multirow{2}{*}{ Breed } & \multicolumn{3}{c}{ CIE-LAB tristimulus values } \\
\cline { 2 - 4 } & $\mathrm{L}^{*}$ (lightness) & $\mathrm{a}^{*}$ (redness) & $\mathrm{b}^{*}$ (yellowness) \\
\hline Charolais & $38.86 \pm 1.24$ & $17.78 \pm 1.02$ & $7.68 \pm 1.03$ \\
Simmental & $37.58 \pm 1.02$ & $20.36 \pm 1.14$ & $7.14 \pm 0.87$ \\
Limousine & $39.74 \pm 0.98$ & $18.87 \pm 1.06$ & $6.21 \pm 0.85$ \\
Hereford & $36.93 \pm 0.85$ & $17.00 \pm 0.98$ & $6.47 \pm 0.89$ \\
Aubrac & $38.23 \pm 1.25$ & $24.23 \pm 1.23$ & $6.80 \pm 0.95$ \\
Angus & $38.17 \pm 1.41$ & $18.05 \pm 1.21$ & $7.22 \pm 1.02$ \\
\hline
\end{tabular}

The data in the Table 3 above shows that the meat of Hereford breed was the lightest, while the Limousine meat was the darkest. The difference reached up to $2.81 \%$ $(P<0.05)$. The meat of Aubrac breed was the reddest, while the Hereford meat was of the lightest red. The difference reached up to $7.23 \%(P<0.01)$. The finding of the yellowness revealed that the meat of Charolais breed was the yellowest, whereas the Limousine meat was of the lightest yellow. The difference reached up to $1.47 \%$ $(P<0.01)$.
The $\mathrm{pH}$ of meat from cattle of different breeds is presented in the Figure 1.

The data presented in the Figure 1 shows that the highest $\mathrm{pH}$ was observed in the meat of Charolais breed, while the lowest $\mathrm{pH}$ was in the Hereford meat. The difference was $0.22 \%(P<0.001)$. Other analysed breeds had a $\mathrm{pH}$ between 5.52 and 5.62.

Physical properties of meat from different breeds are presented in the Table 4. 


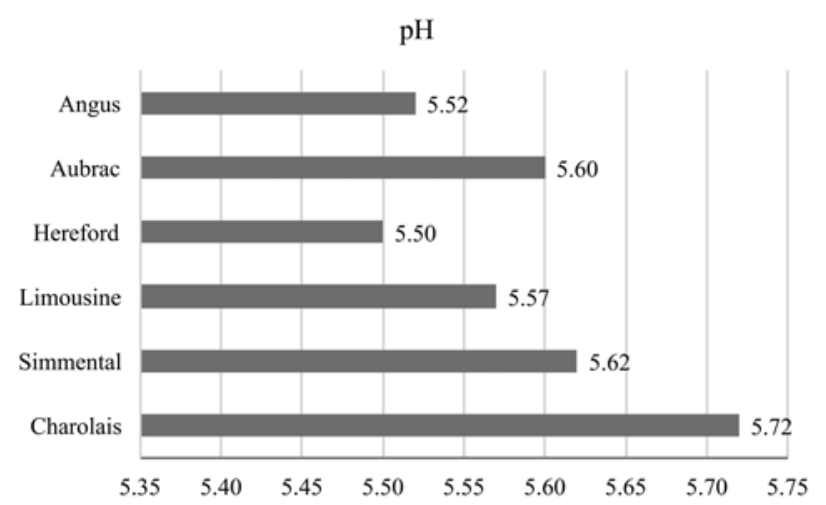

Figure 1. The $\mathrm{pH}$ of meat from cattle of different breeds
According to the results presented in the Table 4, it can be stated that the drip loos in meat, water holding capacity and cooking losses vary depending on the cattle breed. The meat of Charolais breed had the highest drip loss content, while the Simmental beef cattle breed had the lowest. The difference reached up to $3.52(P<0.01)$. The highest water holding content was observed in the meat of Simmental breed, while the lowest water holding capacity was of Aubrac breed meat. The difference reached up to $7.06 \%(P<0.01)$. The highest cooking loss was observed in the meat of Charolais beef cattle breed, while the lowest cooking loss was of the Hereford breed meat. The difference reached up to $5.05 \%(P<0.01)$.

Table 4. Physical properties of meat from cattle of different breeds

\begin{tabular}{|c|c|c|c|}
\hline \multirow[b]{2}{*}{ Breed } & \multicolumn{3}{|c|}{ Physical properties } \\
\hline & $\begin{array}{c}\text { drip loss } \\
\%\end{array}$ & $\begin{array}{c}\text { water holding capacity } \\
\%\end{array}$ & $\begin{array}{c}\text { cooking loss } \\
\%\end{array}$ \\
\hline Charolais & $5.57 \pm 0.23$ & $60.14 \pm 2.26$ & $27.54 \pm 1.25$ \\
\hline Simmental & $2.05 \pm 0.12$ & $62.26 \pm 2.54$ & $24.34 \pm 2.02$ \\
\hline Limousine & $4.26 \pm 0.32$ & $59.92 \pm 3.18$ & $24.26 \pm 2.24$ \\
\hline Hereford & $3.73 \pm 0.15$ & $62.39 \pm 4.02$ & $22.49 \pm 2.98$ \\
\hline Aubrac & $4.04 \pm 0.18$ & $55.20 \pm 2.85$ & $26.53 \pm 1.85$ \\
\hline Angus & $4.61 \pm 0.48$ & $59.61 \pm 2.65$ & $23.73 \pm 2.36$ \\
\hline
\end{tabular}

The toughness of meat from cattle of different breeds is presented in the Figure 2.

According to the data presented in the Figure 2, the meat of Aubrac breed was the toughest, while the meat of Charolais breed was the softest. The difference reached up to $0.9 \mathrm{mg} \mathrm{cm}^{2}(P<0.01)$. Meat toughness indexes of other breeds varied from 2.22 and $2.46 \mathrm{mg} \mathrm{cm}^{2}$ $(P<0.05)$.

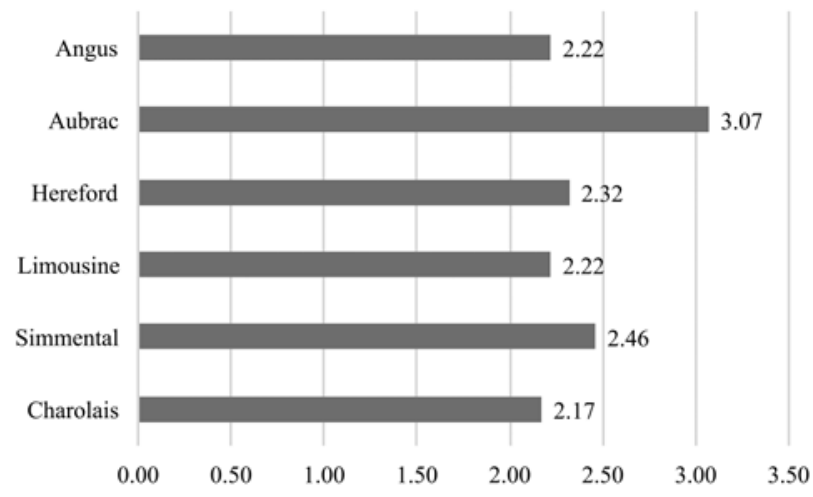

Figure 2. The toughness of meat from cattle of different breeds, $\mathrm{mg} \mathrm{cm}{ }^{2}$

Our study has proved that the meat has different meat quality indexes which depend on the breed of beef cattle. This fact was proved by other researchers as well. Golze and a group of researchers (2009) carried out a comparative study regarding protein amount in the meat of Simmental, Limousine, German Angus and Galloway cows, and had stated that the highest amount of protein was observed in Simmental, while the lowest amount of protein was in the German Angus cattle meat. During other studies, Golze and other researchers (2002) carried out comparative studies regarding physical properties of Simmental, Limousine and Angus breed bull meat, and identified breed differences with respect to the properties of cooking, baking, chroma (colour) $\mathrm{L}$ and toughness. There was no $\mathrm{pH}$ differences identified between various breeds. Martin (2010) compared the meat quality of the Charolais, Ukermarker, Simmental, Limousine, Hereford, Angus, Aubrac and Salers breeds and identified that the breed had an impact on a number of meat quality indexes.

\section{Conclusions}

1. The meat quality of different cattle breeds was influenced differently by the high energy forage. Intramuscular fat content influenced meat flavour and juiciness. Thus, the meat of Charolais and Hereford was of the highest quality, whereas the meat of Aubrac and Limosine was of the lowest quality.

2. The influence of breed on the amount of dry matter in meat was not significant. The meat of the Aubrac breed was the highest in protein, while the meat of Hereford was the lowest. The difference reached up to $1.79 \%(P<0.05)$. Some breed differences regarding the meat toughness were observed as well. The meat of Aubrac was the toughest and the meat of Charolais was the softest. The difference reached up to $0.9 \mathrm{~kg} \mathrm{~cm}^{2}(P<0.01)$. The differences regarding water content in meat, water holding and cooking loss were not significant.

3. The amount of intramuscular fat in meat varied between different breeds. The highest amount of intramuscular fat was observed in the meat of Hereford breed, while the meat of the Aubrac breed was the lowest in intramuscular fat. The difference reached up to $1.48 \%$ $(P<0.05)$.

4. The study revealed that the meat between breeds differs in physical qualities as well. The meat of French breeds (Charolais and Limousine) was brighter, its water holding capacity was higher $-0.78-0.82 \%$ $(P>0.05)$ as compared to early-maturing English breeds (Hereford and Angus). 


\section{References}

1. Aldai N., Dugan M. E. R., Kramer J. K. G., Martinez A., Lopez-Campos O., Mantecon A. R., Osoro K. 2011. Length of concentrate finishing affects the fatty acid composition of grass-fed and genetically lean beef: an emphasis on trans-18:1 and conjugated linoleic acid profiles. Animal, 5 (10): 1643-1652. https://doi.org/10.1017/S1751731111000607

2. Bendikas P., Uchockis V., Tarvydas V., Svirmickas G. 2008. Bull weight gains, carcass and meat quality when fed diets containing rapeseed cake or oil-meal. Gyvulininkyste, 52: 60-70 (in Lithuanian).

3. Bendikas P., Uchockis V., Jonaitis L., Tarvydas V. 2009. The influence of different energy and protein content on weight gains and meat quality of young bulls. Veterinarija ir zootechnika, 45 (67): 8-12 (in Lithuanian).

4. Bratzler L. J. 1932. Measuring the tenderness of meat by means of a mechanical shear. Master of Science thesis, Kansas State College, USA.

5. Chambaz A., Scheeder M. R. L., Kreuzer M., Dufey P. A. 2003. Meat quality of Angus, Simmental, Charolais and Limousine steers compared at the same intramuscular fat content. Meat Science, 63 (4): 491-500. https://doi.org/10.1016/S0309-1740(02)00109-2

6. Culioli J., Berri C., Mourot J. 2003. Muscle foods: consumption, composition and quality. Sciences des Aliments, 23: 13-34.

https://doi.org/10.3166/sda.23.13-34

7. Dierking R. M., Kallenbach R. L., Grün I. U. 2010. The effect of forage species on fatty acid content and performance of pasture-finished steers. Meat Science, 85 (4): 597-605. https://doi.org/10.1016/j.meatsci.2010.03.010

8. Gentleman R., Ihaka R. 1997. An introduction to $R$. Notes on $R$ : a programming environment for data analysis and graphics. $R$ Core Team.

9. Golze M., Strehle S., Schröder Ch., Klos K., Schöberlein L. 2002. Schlaclit Kühe haben begondere wert. Fleisehrinder, 3: 16-17 (in German).

10. Golze M., Strehle S., Schröder Ch., Klos K. 2009. Schlacltkörperwert und Fleisehqualität von Altbulen. Fleisehrinder, 4: 24-28 (in German).

11. Grau R., Hamm R. 1956. Determination of water binding in meat by the pressing method. Fleischwirtschaft, 8: 733736. (in German)

12. Hamm R. 1972. Die Kolloidchemie des Fleisches. Berlin, Hamburg, 275 S. (in German)

13. Jukna Č., Jukna V. 2004. Mèsinių galvijų auginimas, 136 p. (in Lithuanian).

14. Jukna Č., Jukna V., Pečiulaitienè N. 2006. The influence of Lithuanian Black-and-White breed bulls on offsprings fatten and meat traits. Veterinarija ir zootechnika, 36 (58): 27-29 (in Lithuanian).

15. Jukna Č., Jukna V., Pečiulaitienè N., Klementavičiūtė J. 2008. Postmortem changes in bovine muscle electrical conductivity and its relationship to meat quality attributes. Veterinarija ir zootechnika, 41 (63): 60-63 (in Lithuanian).

16. Jukna Č., Jukna V., Korsukovas A., Pečiulaitienè N. 2010 (a). The influence of beef breed bulls on Lithuanian Blackand-White cattle production and quality. Veterinarija ir zootechnika, 49 (71): 20-24 (in Lithuanian).

17. Jukna V., Jukna Č., Pečiulaitienè N. 2009 (a). The beef production efficiency of milk cattle used crossed with different intensive beef cattle breeds. Biotechnology in Animal Husbandry, 25 (5-6): 293-300. https://doi.org/10.2298/BAH0906293J

18. Jukna V., Jukna C., Pečiulaitienè N., Kerinas E. 2009 (b). Influence of cattle sex and age on carcass yield and muscularity class. Veterinarija ir zootechnika, 46 (68): 20-23 (in Lithuanian).
19. Jukna V., Jukna Č., Pečiulaitienė N., Riškevičienė V., Korsukovas A. 2010 (b). Effect of genotype on growth intensity and meat quality of bulls. Veterinarija ir zootechnika, 50 (72): 23-27 (in Lithuanian).

20. Martin J. 2010. Schlacchtviehmarkt bestimnit Effektivität der Mutterkuhhaltung. Fleischrinder, 3: 12-15 (in German).

21. Michal J. J., Zhang Z. W., Gaskins C., Jiang Z. 2006. The bovine fatty acid binding protein 4 gene is significantly associated with marbling and subcutaneous fat depth in Wagyu $\times$ LimousinF2 crosses.AnimalGenetics, 37:400-402. https://doi.org/10.1111/j.1365-2052.2006.01464.x

22. Nuernberg K., Dannenberger D., Nuernberg G., Ender K., Voigt J., Scollan N. D., Wood J. D., Nute G. R., Richardson R. I. 2005. Effect of a grass-based and a concentrate feeding system on meat quality characteristics and fatty acid composition of longissimus muscle in different cattle breeds. Livestock Production Science, 94 (1-2): 137-147. https://doi.org/10.1016/j.livprodsci.2004.11.036

23. Official Methods of Analysis of AOAC International. 2012. AOAC International, Gaithersburg, USA, AOAC SMPR $2011.003\left(19^{\text {th }}\right.$ ed. $)$.

24. Ozluturk A., Tuzemen N., Yanar M., Esenbuga N., Dursun E. 2004. Fattening performance, carcass traits and meat quality characteristics of calves sired by Chalolais, Simmental and Eastern Anatolian Red sires mated to Eastern Anatolian Red dams. Meat Science, 67 (3): 463-470. https://doi.org/10.1016/j.meatsci.2003.11.022

25. Purslow P. 2005. Intramuscular connective tissue and its role in meat quality. Food Science, 70: 435-447. https://doi.org/10.1016/j.meatsci.2004.06.028

26. Raes K., Haak L., Balcaen A., Claeys E., Demeyer D., De Smet S. 2004. Effect of feeding linseed at similar linoleic acid levels on the fatty acid composition of double-muscled Belgian Blue young bulls. Meat Science, 66 (2): 307-315. https://doi.org/10.1016/S0309-1740(03)00105-0

27. Rotta P. P., Prado R. M., Prado I. N., Valero M. V., Visentainer J. V., Silva R. R. 2009. The effects of genetic groups, nutrition, finishing systems and gender of Brazilian cattle on carcass characteristics and beef composition and appearance: a review. Animal Science, 22 (12): 1718-1734. https://doi.org/10.5713/ajas.2009.90071

28. Schonfeldt H. C., Gibson N. 2008. Changes in the nutrient quality of meat in an obesity context. Meat Science, 80 (1): 20-27. https://doi.org/10.1016/j.meatsci.2008.05.025

29. Schwarz F. J., Linden S., Augustini C., Steinhart H. 2003. Effect of diet and added antioxidants on meat quality of beef. EAAP 54 ${ }^{\text {th }}$ Annual Meeting. Book of abstract No. 9. Rome, Italy, p. 130

30. Serdaroglu M. 2006. The characteristics of beef patties containing different levels of fat and oat flour. Food Science, 41: 147-153. https://doi.org/10.1111/j.1365-2621.2005.01041.x

31. Serra X., Gil M., Gispert M., Guerrero L., Oliver M. A., Samido C., Canpo M. M., Panea B., Olleta J. L., Qvintanilla R., Piedrafita J. 2004. Characterisation of young bulls of the Bruna dels Pirineus cattle breed (selected from old Brown Swiss) in relation to carcass, meat quality and biochemical traits. Meat Science, 66 (2): 425-436. https://doi.org/10.1016/S0309-1740(03)00131-1

32. Taniguchi M., Guan L. L., Basarab J. A., Dodson M. V., Moore S. S. 2008. Comparative analysis on gene expression profiles in cattle subcutaneous fat tissues. Comparative Biochemistry and Physiology, 3: 251-256. https://doi.org/10.1016/j.cbd.2008.06.002

33. Vandendriessche F. 2008. Meat products in the past, today and in the future. Meat Science, 78 (1-2): 104-113. https://doi.org/10.1016/j.meatsci.2007.10.003 
34. Vavrišinova K., Privara S., Čubon J., Haščik P., Foltys V. 2013. Veal quality and fatty acids content in Holstein calves at different diets. Veterinary Medicine and Zootechnics, 61 (83): 89-95.

35. Vieira C., Cerdeno A., Serrano E., Lavin P., Mantecon A. R. 2007. Breed and ageing extent on meat carcass and meat quality of beef from adult steers (oxen). Livestock Science, 107 (1): 62-69.

https://doi.org/10.1016/j.livsci.2006.09.004

36. Warner K. F. 1928. Progress report of the mechanical test for tenderness of meat. Proceedings of the American Society of Animal Production, 21: 114
37. Web E. C., O’Neill H. A. 2008. The animal fat paradox and meat quality. Meat Science, 80 (1): 28-36. https://doi.org/10.1016/j.meatsci.2008.05.029

38. Wood J. W., Enser M., Fisher A. V., Nute G. R., Sheard P. R., Richardson R. I., Hughes S. I., Wittington F. M. 2008. Fat deposition, fatty acid composition and meat quality: a review. Meat Science, 78 (2): 343-358.

https://doi.org/10.1016/j.meatsci.2007.07.019

39. Žgur S., Čepon M., 2007. Fat tissue distribution between subcutaneous and intramuscular fat tissue in Simmental and brown bulls. Poljoprivreda: Agriculture, 13 (1): 120-123.

ISSN 1392-3196 / e-ISSN 2335-8947

Zemdirbyste-Agriculture, vol. 104, No. 3 (2017), p. 277-282

DOI $10.13080 / \mathrm{z}-\mathrm{a} .2017 .104 .035$

\title{
Didelès energinès vertès pašarų įtaka ịvairių veislių mèsinių galvijų mèsos kokybei
}

\author{
V. Jukna ${ }^{1}$, Č. Jukna ${ }^{2}$, V. Prusevičius ${ }^{3}$, E. Meškinytè-Kaušiliené ${ }^{4}$, N. Pečiulaitienè ${ }^{2}$ \\ ${ }^{1}$ Aleksandro Stulginskio universiteto Energetikos ir biotechnologijų inžinerijos institutas \\ ${ }^{2}$ Lietuvos sveikatos mokslų universiteto Veterinarijos akademija \\ ${ }^{3}$ Lietuvos Respublikos žemès ūkio ministerija \\ ${ }^{4}$ Aleksandro Stulginskio universiteto \\ Gyvulininkystès selekcijos, veislinès vertès nustatymo ir sklaidos centras
}

\section{Santrauka}

Tyrimo tikslas - ištirti skirtingų mėsinių galvijų veislių mėsos kokybės pokyčius, kai buvo šerta didelès energinès vertės pašarais. Tyrimui buvo sukomplektuotos dvi grupès nekastruotų 200 dienų amžiaus veislių Limuzinų, Šarolè, Angusų, Herefordų ir Simentalių bulių po 10 gyvulių kiekvienoje. Buliukai buvo auginti vienodomis šèrimo ir laikymo sąlygomis. Gyvuliai koncentruotų pašarų gavo normuotai, o siloso galèjo ėsti iki soties. Likusią dalị pašaro sudarè daug smulkių žolių ir kukurūzų silosas. Pasiekus vidutiniškai 500 dienų amžių iš grupès buvo atrinkta po 5 buliukus, labiausiai atitinkančius grupès vidurkị, ir atliktas jų kontrolinis skerdimas. Didžiausias kiekis baltymų nustatytas Aubrakų veislès galvijų mėsoje, mažiausias - Herefordų veislès galvijų mėsoje, skirtumas sudarè 1,79 $\%(P<0,05)$. Nustatyta neesminè veislès įtaka mėsos sausųjų medžiagų kiekiui. Gauti skirtumai tarp veislių, susiję su mėsos kietumu: kiečiausia buvo Aubrakų veislès galvijų mėsa, švelniausia - Šarolè veislès, skirtumas sudare 0,9 $\mathrm{kg} \mathrm{cm}^{-2}(P<0,01)$. Nustatyti neesminiai skirtumai tarp veislių, susiję su mėsos vandeningumu, vandens rišlumu ir virimo nuostoliais. Didžiausias kiekis tarpraumeninių riebalų nustatytas Herefordų veislès mèsoje, mažiausias - Aubrakų veislès, skirtumas sudarè 1,48 \% $(P<0,05)$. Prancūziškų veislių (Šarolè ir Limuzinų) bulių mèsa buvo šviesesnè, jos vandens rišlumas didesnis $-0,78-0,82 \%(P>0,05)$, palyginus su greitai bręstančių angliškų veislių (Herefordų ir Angusų) bulių mèsa $(P>0,05)$.

Reikšminiai žodžiai: buliai, grynaveislis, koreliacija, mėsos kokybė, pašarai. 